\title{
Infection rates and prevalence of metazoan parasites of the non-native round goby (Neogobius melanostomus) in the Baltic Sea
}

\author{
Heidi Herlevi • Riikka Puntila $(\mathbb{D} \cdot$ Harri Kuosa $\cdot$ Hans-Peter Fagerholm
}

Received: 8 April 2016/Revised: 17 November 2016/Accepted: 18 November 2016/Published online: 23 December 2016 (C) The Author(s) 2016. This article is published with open access at Springerlink.com

\begin{abstract}
Studies in the Baltic Sea have identified over 30 parasite taxa infecting the invasive round goby (Neogobius melanostomus (Pallas, 1814). In this study, we aimed at comparing parasite assemblages and infection rates (prevalence and intensity) in different populations across the invasive range in the Baltic Sea (Denmark, Lithuania, Estonia and Finland). Infection rates were 56-60\% across all locations except Lithuania (28\%). However, the parasite assemblages in the sampled populations were dissimilar, each location having unique parasites. In addition,
\end{abstract}

Handling editor: Jonne Kotta

H. Herlevi

Environmental and Marine Biology, Faculty of Science and Engineering, Åbo Akademi University, Tykistökatu 6, 20520 Turku, Finland

\section{R. Puntila ( $\square)$}

Department of Aquatic Sciences, University of Helsinki, P.O. Box 65, Biocenter 3, Viikinkaari 1, 00014 Helsinki, Finland

e-mail: riikka.puntila@helsinki.fi

R. Puntila $\cdot$ H. Kuosa

Marine Research Center, Finnish Environment Institute, P.O. Box 140, 00251 Helsinki, Finland

\section{H.-P. Fagerholm}

Åbo Akademi University, Faculty of Science and Engineering, Environmental and Marine Biology, Laboratory of Aquatic Pathobiology, Tykistökatu 6, 20520 Turku, Finland many of the parasites were generalists commonly infecting native fish species. Based on the results of this study and those previously conducted in the Baltic Sea, the round goby has not retained parasites from its area of origin, but instead has been successively colonized by native generalist parasites. Although variable, overall parasite richness is still quite low around the Baltic compared to the native areas (34 vs 71 taxa, respectively). Also, prevalence and mean infection intensities in the Baltic Sea are significantly lower than in the native areas. Therefore, the invasion success of the round goby in the Baltic Sea can at least partly be attributed to enemy release, in this case shedding a significant proportion of their native parasite load.

Keywords Parasite prevalence $\cdot$ Parasite assemblages $\cdot$ Enemy release $\cdot$ Invasion $\cdot$ Invasion ecology

\section{Introduction}

The round goby (Neogobius melanostomus (Pallas, 1814) is one of the most widespread non-native fish species in the Baltic Sea (Kotta et al., 2016), with reported detrimental biological impacts in many locations (Ojaveer \& Kotta, 2015; Ojaveer et al., 2015). Following its initial detection in the Gulf of Gdansk in 1990 (Skora \& Stolarski, 1993), it spread throughout the southern Baltic Sea, eastward to the 
Vistula lagoon and river system (Mierzejewska et al., 2011), westward to the German and Danish coastal areas and further north along the southeastern coast of Sweden (Florin \& Karlsson, 2011; Sapota, 2011). In the northern parts of the Baltic Sea, round goby became a permanent component of the Lithuanian, Latvian and Estonian coastal fish fauna in the 2000s (Ojaveer, 2006; Sapota, 2011; Rakauskas et al., 2013; Strake et al., 2013). By 2011, the species had been recorded along the Finnish coast of the Gulf of Finland, in the Archipelago Sea and the Åland Islands. The northernmost observations to date were made in 2013 outside the town of Raahe (about $64^{\circ} 4^{\prime} \mathrm{N}$ ) in the Bothnian Bay. Currently, the species has been observed along the coasts of all Baltic sub-basins, except for the Swedish coast of the Bothnian Bay (Kotta et al., 2016). Although originating from the brackish waters of the Black Sea and Sea of Azov, the species has also established viable and flourishing populations in many freshwater areas throughout European river systems (e.g. van Beek, 2006; Ondračková et al., 2010; Borcherding et al., 2011; Emde et al., 2012; Huyse et al., 2015) and the North American Great Lakes (Kornis et al., 2013).

The great invasion success of the species has partly been explained by its pronounced phenotypic plasticity in terms of life-history traits (MacInnis \& Corkum, 2000; Gutowsky \& Fox, 2012; Brandner et al., 2013a), feeding habits (Brandner et al., 2013b) as well as tolerance of different salinity regimes (Karsiotis et al., 2012; see review by Kornis et al., 2012). Many researchers have also suggested the lack of natural enemies as a major contributing factor (Sapota \& Skora, 2005; Kvach \& Skóra, 2006; Kvach \& Stepien, 2008; Gendron et al., 2012). Parasites are important biological regulators and occur as an inherent part of any biological community (e.g. Williams et al., 1992). They can also be seen as a good indicator of the ecosystem health (Hudson et al., 2006; Palm, 2011). The lack of such natural regulators has-in accordance with the enemy release hypothesis-been pointed out as one of the reasons to the successful colonization and population expansion of many introduced species (Torchin et al., 2003; Colautti et al., 2004). Introduced species are known to have an impact on the native fauna in not only many direct ways, e.g. through competition and predation, but also indirectly by acting as a vector for new parasites and pathogens (Ruiz et al., 1999; Emde et al., 2012). This spillover effect of non-indigenous parasites being introduced to new ecosystems together with their non-indigenous hosts has been discussed in numerous studies (e.g. Johnsen \& Jenser, 1991; Prenter et al., 2004; Peeler et al., 2010; Lymbery et al., 2014). Kelly et al. (2009) highlighted the significance of the spillback of native parasites, i.e. when non-native species act as a new competent intermediate and/or paratenic host for native parasites. This spillback may be of pronounced ecological significance, as it facilitates the transmission of parasites to native hosts and can increase the prevalence of diseases in a population (Kelly et al., 2009 and references therein). However, non-native species may also alleviate the parasitic load of native species by 'diluting' the intensity of infection, e.g. when replacing native host species and acting as a "resistant target" (Kopp \& Jokela, 2007). Thus, nonnative species can simultaneously play many different roles in the parasite-host cycle.

The round goby was most probably transported to the Gulf of Gdansk in ballast water as eggs or larvae (Sapota \& Skora, 2005). It is not known whether the source population is from the Black, Azov or Caspian Sea and whether it arrived via the inland river systems of Don/Volga or Dnieper-Vistula, but the species was most likely transported to the Baltic with the ballast water of vessels (Sapota, 2004). This comparatively rapid translocation, together with a steep decline in salinity (16-18 PSU in the Black Sea vs. 7-8 PSU in the Gulf of Gdansk) may have caused the loss of most of the native parasite fauna (Kvach et al., 2014). In a recent study, Kvach et al. (2014) found that the round goby had relatively many (15 species) metazoan parasite species in its native area (the Danube estuary) compared to other gobiid species, but had retained very few when the round goby invaded Vistula delta (5 species). Conversely, the racer goby (Babka gymnotrachelus, Kessler, 1857) has lower parasite richness in the native than in the invasive range (Kvach et al., 2014). Many previous results, in addition to the above, show that the round goby may be benefitting from decreased parasite load, supporting the enemy release hypothesis (ERH) (Kvach, 2001; Kvach \& Skóra, 2006; Francová et al., 2011; Emde et al., 2012).

Studies have shown that so far the round goby has relatively low infection rates in the Baltic (some 7-20 taxa; Rolbiecki, 2006; Rakauskas et al., 2008) compared to its native range (Kvach 2005) (up to 71 taxa and overall infection rate of up to $97 \%$; Rolbiecki, 
2006; Özer, 2007). All parasites found in the Baltic populations have also been previously recorded in the Baltic Sea (Rolbiecki, 2006; Kvach \& Winkler, 2011). Therefore, there is no indication of spillover of nonnative parasites into the Baltic Sea, which was an obvious concern knowing that some non-indigenous fish have introduced invasive and severely harmful parasites to native species (e.g. Johnsen \& Jenser, 1991; Lymbery et al., 2014). However, in the Vistula Lagoon, the round goby has been reported to host larvae of the introduced swim bladder nematode Anguillicoloides crassus (Kuwahara, Niimi \& Itagaki, 1974) (Kvach, 2004a; Rolbiecki, 2006), which may lead to further spread and transmission to its definitive host, the European eel (Anguilla anguilla, L., 1758), whose populations are already declining in the Baltic Sea (Kirk, 2003; Kvach, 2004a; Rolbiecki, 2006). While not currently found parasitizing the round goby in the Baltic Sea, the goby-specific Ponto-Caspian monogenean Gyrodactylus proterorhini (Ergens, 1967), has been transferred to the Vistula basin by other Ponto-Caspian gobies (Mierzejewska et al., 2011) and is more abundant in the non-native than in the native areas (Kvach et al., 2014). In other invaded fresh water habitats, like the Rhine River, round goby is also suspected to aid in the spreading of the nonnative acanthocephalan parasite Pomphorhynchus tereticollis (Rudolphi, 1809) (Emde et al., 2012), and although this particular species is already a part of the parasite fauna in the Baltic Sea (Špakulová et al., 2011), it shows that the round goby has a potential of transmitting parasites to new areas as it continues to spread.

Populations of the round goby across the Baltic Sea are very different. They have a very different invasion history primarily in terms of time since introduction: the most recent introductions and oldest ones are more than 20 years apart (Sapota, 2011; Kotta et al., 2016). Also, the populations are exposed to very different abiotic conditions due to the pronounced gradients in both salinity and temperatures in the Baltic Sea and, therefore, different local parasite assemblages. The population age, i.e. time since introduction, is often reflected in the parasite loads as the infection rates increase the older the population. This has been true, for example, in the Gulf of Gdansk, where the parasite abundance of the round goby increased from six species in the first studies (Rokicki \& Rolbiecki, 2002) to at least 12 metazoan parasite species by 2006
(Kvach \& Skóra, 2006). In the most recently established populations, the infection rates are presumably still low due to fewer parasitic species adapted to this new host.

Studies focusing on round goby parasites in the Baltic Sea have been quite few, spatially limited to local studies on German, Polish and Lithuanian populations and completely lacking in the northern Baltic Sea (Kvach, 2001, 2004a; Kvach \& Skóra, 2006; Rakauskas et al., 2008; Kvach \& Winkler, 2011). The aim of the present study was to identify, quantify and compare the most common metazoan parasites (concentrating on metazoan endoparasites) infecting the round goby in four distinct locations in the Baltic Sea. In addition, we also review the existing literature on the round goby parasites in the region, and compare and contrast them to the results of this study.

\section{Material and methods}

Round gobies were collected from four locations around the Baltic Sea (Denmark, Lithuania, Estonia and Finland [the ̊land islands]) (Fig. 1). The sampling was conducted in June 2015 using identical trap assays at each site (see below). The sites were chosen based on the previous observations of the round goby as these are the locations where the species was first discovered and populations are established and round gobies are abundant (Sapota, 2004; Ojaveer, 2006; Azour et al., 2015; Kotta et al., 2016). The habitat at all sampling locations consisted of vegetated sandy bottoms, except in Finland and Estonia where the bottom substrate consisted mainly of coarse gravel and rocks interspersed with sandy patches. This reflects a general change in dominant habitats from southern to northern Baltic Sea. The locations in Lithuania, Estonia and Finland were also close to artificial structures such as piers or built embankments, which has been noted as the round gobies preferred habitat as they provide suitable nesting sites and shelter (MacInnis \& Corkum, 2000; Sapota \& Skora, 2005; Ojaveer, 2006). The populations differ as to the time of invasion: the Lithuanian population around Klaipeda was discovered in 2002 (Sapota, 2011) and the population in Muuga, Estonia (Gulf of Finland) was discovered two years later in 2004 (Ojaveer, 2006). The first records of the round goby from Guldborgsund 

around the Baltic Sea (see Table 1 for more information) and the prevalence of parasite infection at each location
Fig. 1 Sampling sites

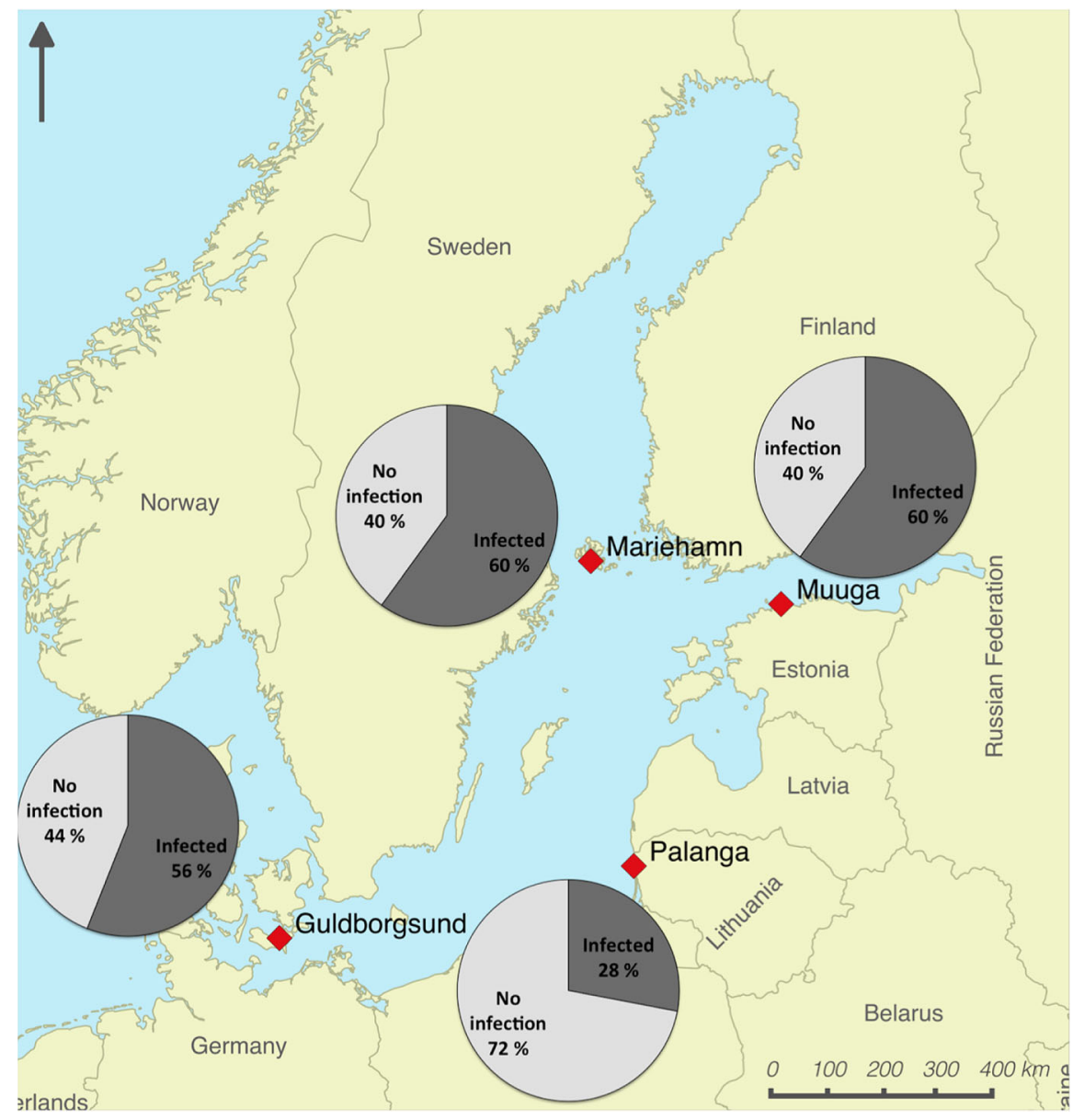

Table 1 Hydrographic data during sample collection at each site

\begin{tabular}{lllc}
\hline Site & Sampling date & Temperature $\left({ }^{\circ} \mathrm{C}\right)$ & Salinity (PSU) \\
\hline 1. Guldborgsund (DK) & 25.05 .2015 & 16.7 & 11.9 \\
2. Palanga (LT) & 08.06.2015 & 15.6 & 5.8 \\
3. Muuga (EE) & 16.06. and 09-17.07.2015 & $15.0-17.0$ & 6.0 \\
4. Mariehamn (FI) & 26.06.2015 & 15.1 & 5.8 \\
\hline
\end{tabular}

(GBS), Denmark, are from 2008 (Azour et al., 2015) and the population in Mariehamn, Aland islands, was first recorded in 2011 (Kotta et al., 2016).

Hydrographic information from each site at the time of sample collection is presented in Table 1. Fish were collected using three types of passive gear; 5 minnow traps (mesh size $6 \mathrm{~mm}$ ), 10 collapsible crayfish traps (mesh size $12 \mathrm{~mm}$ ) and 3 eel traps (mesh size in cod ends 10, 14 and $17 \mathrm{~mm}$ ). This combination was used to provide a better size range of catch than any trap type used alone. The traps were placed at approximately 2-m intervals parallel to the shoreline at 1-2 $\mathrm{m}$ depth and checked every $24 \mathrm{~h}$ during 3 days. A piece of frozen herring (or other locally available fish) was placed in sealed mesh bags inside the minnow and crayfish traps and baits were replaced as needed. The use of both baited and unbaited methods also gives a more representative sample of the population. The sampling procedure remained the same throughout the locations to enable 
comparisons between locations. Fish from each sampling time $(n=3)$ and trap type $(n=3)$ were placed in separate bags and 3-4 fish were haphazardly taken from each bag for inspection so that a total number of 25 of round gobies per site, representing various sizes, were randomly selected for closer inspection. The collected fish were immediately terminated and frozen $\left(-18\right.$ to $\left.-20^{\circ} \mathrm{C}\right)$ until examined. Before dissection, they were measured (total length, TL, in $\mathrm{mm}$ ), weighed ( $\mathrm{W}$, in $\mathrm{g}$ ) and their sex was determined. Their livers were extracted and weighed to obtain an estimate of health and energy reserves expressed as hepatosomatic index (HSI) $(\mathrm{HSI}(\%)=100 \times($ liver weight $[\mathrm{g}] /$ whole fish weight $[\mathrm{g}])$ ). In addition, the condition of the inspected fish was expressed using the Fulton's K index (Fulton, 1904) as $K=100 \times W[\mathrm{~g}] /$ $\mathrm{TL}[\mathrm{cm}]^{3}$. Differences in fish condition between sites were tested using analysis of variances (ANOVA) and post hoc comparisons using the Tukey HSD procedure. Hepatosomatic index was log-transformed to fulfil the assumptions for parametric analyses.

The skins, fins and gills were carefully examined visually in case of signs of ectoparasites (or larval stages of endoparasites like metacercariae of digenean trematodes) and all anomalies in appearance were noted. All ectoparasite taxa are typed in italics (Tables 4 and 6) to allow for comparisons with the previously published studies. Opaque eyes can be a sign of Diplostomum spp. metacercariae larvae, which infect the lens of the eye and have been found in previous studies as one of the most abundant parasites of the round goby in the Gulf of Gdansk (Kvach \& Skóra, 2006; Rolbiecki, 2006). The eyes of each fish were dissected and inspected carefully under a dissection microscope.

The entire intestinal tract was then removed for inspection of endoparasites on both inner and outer intestinal surfaces. The gut contents were removed and the digestive tract inspected carefully for parasites. Food items in the stomach and gut were also recorded by examining the contents under a microscope and identifying which taxa were present. The number of taxa in each stomach and the frequency of occurrence (FO $\%=$ stomachs including prey item "i" out of a total number "n" of stomachs with contents at location " $x$ "; Hyslop, 1980) were calculated. This was done to get a picture of which taxa are being consumed at each location at the time of sampling. The body cavity and organs (gonads, kidney, liver, mesenteries and spleen) were inspected under a dissection microscope. All parasites were counted and stored in $70 \%$ alcohol prior to a more detailed examination and identification. Digenean trematode larvae and Hirudinea were identified according to descriptions in Valtonen (2012). Often the Diplostomid larvae found in the lens of fish have been identified as Diplostomum spathaceum (Höglund \& Thulin, 1982), but as studies have shown there are at least two species infecting the lens (Valtonen \& Gibson, 1997), and D. spathaceum is most likely a conglomeration of species. Thus, all Diplostomid larvae in this study were assigned to Diplostomum spp. since no genetic verification was made. Nematodes and Acanthocephalans were cleared in lacto phenol before examination under a light microscope. Identification was done according to morphological descriptions of, e.g. foregut, head and tail structures of nematodes in Fagerholm (1982) and Moravec (1994). Acanthocephalans were identified according to a key (Arai, 1989) and descriptions by Valtonen (2012).

The parasitological indices were calculated according to Rózsa et al. (2000) as: prevalence (proportion of fish infected of all fish examined/site), mean intensity (MI) and median intensity (mean and median number of parasites in infected fish, MedI) and their ranges given as confidence limits obtained by bootstrapping (Rózsa et al., 2000) using the Quantitative Parasitology 3.0 software (Reiczigel \& Rózsa, 2005). The differences in parasite prevalence between the sampling locations and sexes were analysed using the Fisher's exact test and the mean intensities between the locations and sexes analysed using the non-parametric Wilcoxon's test due to the skewed nature of the infection intensity data. Multiple comparisons (post hoc tests) were conducted using the non-parametric Steel-Dwass method (Critchlow \& Fligner, 1991). In addition, the differences in parasite assemblages between the locations were analysed using analysis of similarities (ANOSIM) and taxa contributing the most to the observed differences were determined by similarity percentage analysis (SIMPER).

All statistical analyses were conducted using the JMP Pro 11 software (SAS Institute Inc., 2013), except the comparisons of the parasite assemblages in the infected fish between sampling locations, which were made using ANOSIM (analysis of similarities) and SIMPER (similarity percentages analysis) in Primer v6 software (Clarke \& Gorley, 2006). 


\section{Results}

Overall condition of the round gobies in different locations

Out of a total of 100 fish that were examined, 32 were females and 68 males (Table 2). Both males and females were the smallest in Guldborgsund (TL 64-133 mm), whereas males were the largest in Mariehamn (mean TL 152,5 \pm 23,5 mm) and females in Palanga (TL 77-198 mm) (Table 2). No females were caught in Mariehamn. The hepatosomatic Index (HSI) varied between the locations $(\mathrm{F}(3107)=9.49$, $P=0.0001)$. Fish from both Muuga $(P=0.0002)$ and Mariehamn $(P=<0.0001)$ had a highly significantly higher HSI than in Guldborgsund and significantly higher in Palanga $(P=0.035)$. The condition index (Fulton's K) was similar throughout the sampling locations $(\mathrm{F}(3,96)=0.587, P=0.625)$ and the infection intensity had no impact on either HSI or Fulton's K $\quad(\mathrm{F}(1,50)=2.42, \quad P=0.126 \quad$ and $\mathrm{F}(1,50)=2.67, P=0.109$, respectively).

Table 2 Number of fish, the total length (TL) and weight of round gobies inspected per site

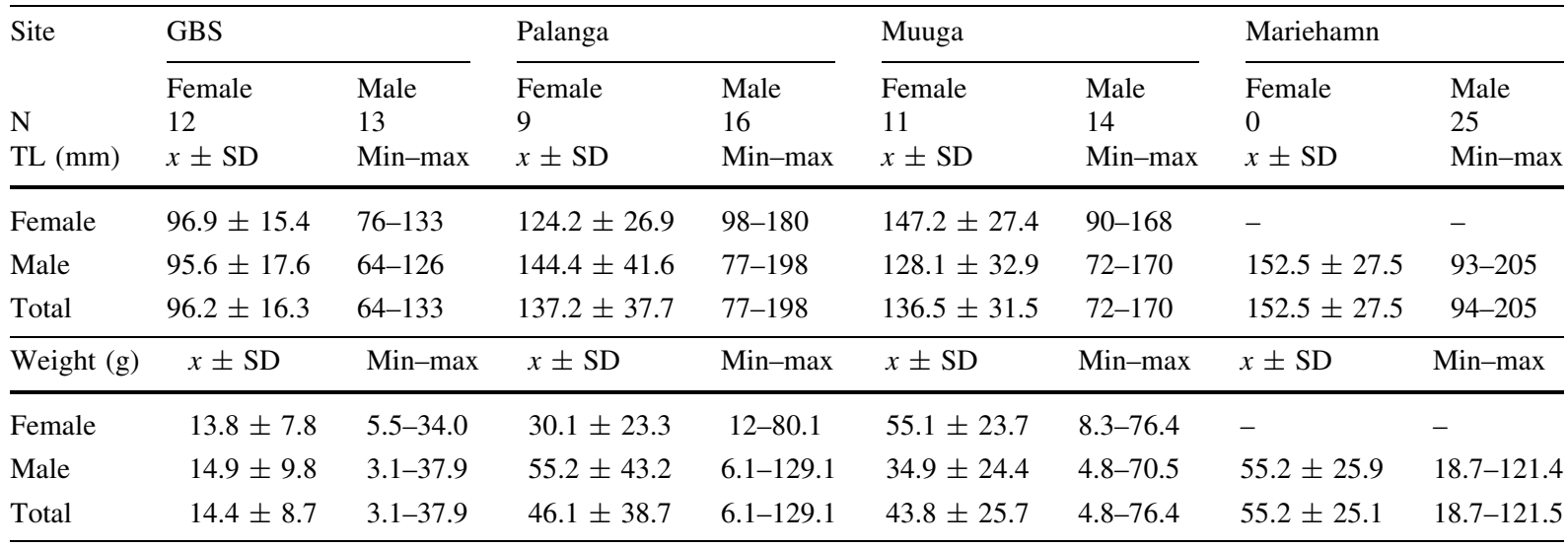

Length and weight are presented as mean and standard deviation together with the range for each parameter. Each parameter is given separately for both sexes and as a total per location

Table 3 Number of infected and non-infected fish, prevalence (\%) of infection, and mean and median intensities of infections (MI and MedI, respectively) at each location

\begin{tabular}{|c|c|c|c|c|c|c|c|c|c|c|c|c|}
\hline Site & Sex & $\mathrm{N}$ & Infected & Prev. & $\begin{array}{l}\text { Lower } \\
\text { CL }\end{array}$ & $\begin{array}{l}\text { Upper } \\
\text { CL }\end{array}$ & MI & $\begin{array}{l}\text { Lower } \\
\text { CL }\end{array}$ & $\begin{array}{l}\text { Upper } \\
\text { CL }\end{array}$ & MedI & $\begin{array}{l}\text { Lower } \\
\text { CL }\end{array}$ & $\begin{array}{l}\text { Upper } \\
\text { CL }\end{array}$ \\
\hline \multirow[t]{3}{*}{ Guldborgsund } & & 25 & 14 & 0.56 & 0.35 & 0.76 & 9.14 & 4.71 & 15.30 & 5 & 2 & 5 \\
\hline & M & 13 & 6 & 0.46 & 0.19 & 0.75 & 7.50 & 2.17 & 21.80 & 3.5 & 1 & 31 \\
\hline & $\mathrm{F}$ & 12 & 8 & 0.67 & 0.35 & 0.90 & 10.40 & 4.38 & 19.90 & 5 & 2 & 26 \\
\hline \multirow[t]{3}{*}{ Palanga } & & 25 & 7 & 0.28 & 0.15 & 0.54 & 2.12 & 1.00 & 4.75 & 1 & 1 & 3 \\
\hline & M & 16 & 4 & 0.25 & 0.07 & 0.52 & 1.50 & 1.00 & 2.00 & 1 & - & - \\
\hline & $\mathrm{F}$ & 9 & 3 & 0.33 & 0.14 & 0.79 & 2.75 & 1.00 & 4.50 & 1 & - & - \\
\hline \multirow[t]{3}{*}{ Muuga } & & 25 & 15 & 0.60 & 0.39 & 0.79 & 6.60 & 3.20 & 7.67 & 3 & 2 & 9 \\
\hline & M & 14 & 7 & 0.50 & 0.23 & 0.77 & 5.29 & 1.86 & 10.10 & 2 & 1 & 16 \\
\hline & $\mathrm{F}$ & 11 & 8 & 0.73 & 0.39 & 0.94 & 5.00 & 2.88 & 7.62 & 4 & 1 & 9 \\
\hline \multirow[t]{3}{*}{ Mariehamn } & & 25 & 15 & 0.60 & 0.39 & 0.79 & 7.93 & 4.00 & 16.50 & 3 & 1 & 7 \\
\hline & M & 25 & 15 & 0.60 & 0.39 & 0.79 & 7.93 & 4.00 & 16.50 & 3 & 1 & 7 \\
\hline & $\mathrm{F}$ & 0 & - & - & - & - & - & - & - & - & - & - \\
\hline
\end{tabular}

The range is expressed as confidence limits (CL) 
Parasite prevalence, infection intensity and assemblages in different locations

In total $51 \%$ of the fish examined were infected by at least one parasite taxa (Table 3). Overall, $383 \mathrm{spec}-$ imens of metazoan parasites representing 10 taxa (3 species of Trematoda (Digenea), 3 Nematoda, 3 Acanthocephala and 1 Hirudinea) were identified (Table 4).

In Muuga, $73 \%$ of all females were infected, whereas the total prevalence was $60 \%$ in both Muuga and Mariehamn (Fig. 1). These two sites had the highest prevalence, compared to $56 \%$ in GBS and $28 \%$ in Palanga (Fig. 1, Table 3), although the differences were non-significant (Fisher's exact test,
2 -sided, $P=0.164)$. Similarly, there was no significant difference in prevalence between the sexes (Fisher's exact test, 2-sided, $P=0.199$ ). The observed numbers of parasite taxa were similar throughout the locations: three in GBS and Muuga, four in Palanga and five in Mariehamn (Table 4). The populations in Muuga and Mariehamn had the highest infection intensity (number of parasites in one fish) with a maximum of 99 and 121 parasite individuals observed. Overall infection intensity was very close to significantly higher in females than males $(Z=1.93$, $P=0.052$ ). The infection intensity (mean intensity) varied between the locations $\left(X^{2}(3, N=52)=8.29\right.$, $P=0.040$; Table 5). These differences are mainly driven by Palanga, which had significantly lower

Table 4 Parasites of N. melanostomus at four locations in the Baltic Sea

\begin{tabular}{|c|c|c|c|c|c|c|c|c|c|c|c|c|c|}
\hline \multirow[t]{2}{*}{ Parasite species, stage } & \multirow[t]{2}{*}{ Location } & \multicolumn{3}{|c|}{ Guldborgsund } & \multicolumn{3}{|c|}{ Palanga } & \multicolumn{3}{|c|}{ Muuga } & \multicolumn{3}{|c|}{ Mariehamn } \\
\hline & & $\mathrm{P}$ & MI & I & $\mathrm{P}$ & MI & I & $\mathrm{P}$ & MI & I & $\mathrm{P}$ & MI & I \\
\hline \multicolumn{14}{|l|}{ Trematoda (Digenea) } \\
\hline $\begin{array}{l}\text { Cryptocotyle sp., met. } \\
\text { 1825) }\end{array}$ & Skin, fins & 40 & 9 & $5-30$ & & & & & & & & & \\
\hline $\begin{array}{l}\text { Diplostomum spp., met. } \\
\text { (Rudolphi, 1819) }\end{array}$ & Eye, lens & & & & & & & 52 & 6 & $1-16$ & 40 & 10 & $1-36$ \\
\hline $\begin{array}{l}\text { Tylodelphys clavata, met. } \\
\text { (Nordmann, 1831) }\end{array}$ & Vitreous body & & & & & & & 12 & 4 & $1-7$ & & & \\
\hline \multicolumn{14}{|l|}{ Nematoda } \\
\hline Camallanus sp., ad. & Intestine & & & & & & & & & & 8 & 2 & $1-2$ \\
\hline Contracaecum spp., L3 & On intestine & 12 & 2 & $1-4$ & & & & & & & & & \\
\hline $\begin{array}{l}\text { Hysterothylacium aduncum L3, } \\
\text { L4, ad. (Rudolphi, 1802) }\end{array}$ & Intestine, mesentery & & & & 16 & 3 & $1-7$ & & & & & & \\
\hline $\begin{array}{l}\text { Ascaridoidea indet., encysted } \\
\text { larvae }\end{array}$ & $\begin{array}{l}\text { Intestinal wall, } \\
\text { mesenteries, body } \\
\text { cavity }\end{array}$ & 16 & 1 & 1 & 4 & 1 & 1 & 12 & 1 & 1 & 12 & 1 & 1 \\
\hline \multicolumn{14}{|l|}{ Acanthocephala } \\
\hline Corynosoma sp., cysth. & Intestine & & & & & & & & & & 4 & 1 & 1 \\
\hline $\begin{array}{l}\text { Echinorhynchus gadi, ad. } \\
\quad \text { (Müller, 1776) }\end{array}$ & Intestine & & & & 4 & 1 & 1 & & & & & & \\
\hline $\begin{array}{l}\text { Pomphorhynchus laevis, cysth. } \\
\text { (Müller, 1776) }\end{array}$ & Intestinal mesentery & & & & 8 & 1 & 1 & & & & & & \\
\hline \multicolumn{14}{|l|}{ Hirudinea } \\
\hline \multirow[t]{2}{*}{ Piscicola geometra ${ }^{\mathrm{c}}($ L., 1761) } & Skin & & & & & & & & & & 4 & 1 & $1-2$ \\
\hline & Total & 56 & 9 & $1-31$ & 28 & 2 & $1-8$ & 60 & 7 & $1-16$ & 60 & 8 & $1-36$ \\
\hline
\end{tabular}

The primary site of infection, prevalence in percent (P), mean intensity (MI) and intensity (min-max) is given for each species/taxa, as well as, a total at each site

Met metacercariae larvae; L3, L4 stage 3 and 4 larvae; cysth cystacanth larvae; ad adult

${ }^{\text {a }}$ Metacercariae capsules (black pigmentation) counted

b Identification based on ecological characteristics

c Found unattached to fish, in the bag with sampled fish 
Table 5 Results of non-parametric analyses of variances (Wilcoxon's test) and multiple comparisons (Steel-Dwass method) of the mean intensities of parasite infection between the different locations

\begin{tabular}{|c|c|c|c|c|}
\hline $\begin{array}{l}\text { Wilcoxon test } \\
\text { Overall } \\
\text { Multiple comparisons }\end{array}$ & $\begin{array}{l}X^{2} \\
8.29 \\
\text { Mean difference }\end{array}$ & $\begin{array}{l}\text { DF } \\
3 \\
\text { SE dif }\end{array}$ & $\begin{array}{l}P \text { value } \\
0.0404 \\
\mathrm{Z}\end{array}$ & $P$ value \\
\hline Muuga: Mariehamn & 2.6 & 3.19 & 0.82 & 0.8474 \\
\hline Muuga: Guldborgsund & -1.38 & 3.13 & -0.44 & 0.9713 \\
\hline Mariehamn: Guldborgsund & -2.21 & 3.12 & -0.71 & 0.8938 \\
\hline Palanga: Mariehamn & -4.89 & 2.80 & -1.75 & 0.2999 \\
\hline Palanga: Guldborgsund & -7.17 & 2.78 & -2.58 & 0.0485 \\
\hline Palanga: Muuga & -7.95 & 2.92 & -2.73 & 0.0324 \\
\hline
\end{tabular}

Significant differences are indicated in bold

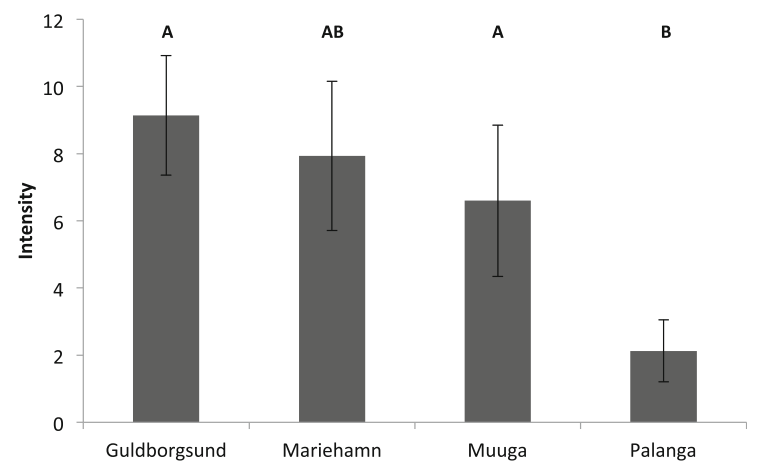

Fig. 2 Differences in mean intensity (MI) of parasite infection between the sampling locations. Variability expressed as standard error. Same letters shared among the groups indicate no significant difference according to the Steel-Dwass method (post hoc test)

mean intensities than Guldborgsund and Muuga (Fig. 2; Table 5).

The non-parametric analysis of similarities shows that parasite assemblages were significantly dissimilar (Global $R=0.442, P=0.001)$. Dissimilarity was largest between Muuga and Palanga $(R=0.753$, $P=0.001$; Table 6) and smallest (NS) between
Muuga and Mariehamn (Table 6). Analysis of Similarity Percentages (SIMPER) revealed that the differences were driven largely by the differences in abundance of Diplostomum spp. and their absence in Palanga, as well as, the presence of $H$. aduncum in Palanga (Table 4). Guldborgsund had the lowest similarity with all other sites, which was primarily explained by the presence of Cryptocotyle sp. in Guldborgsund and its absence elsewhere (Table 4). All sampled populations hosted at least one unique parasite taxa, which was not found in any of the other populations.

Parasite taxa found in the different locations

\section{Guldborgsund, GBS (Denmark)}

In Guldborgsund, 14 of the 25 fish inspected (56\%) were infected by parasites (Table 3). Mean intensity was 9 and maximum intensity was 31 individuals (Table 4). The most common parasite in the round goby population, infecting $40 \%$ of the fish inspected, was the metacercariae larvae of Cryptocotyle sp.

Table 6 ANOSIM table of Global R values and their significance indicating differences in parasite assemblages between the sites

\begin{tabular}{lllll}
\hline & Guldborgsund & Palanga & Muuga & Mariehamn \\
\hline Guldborgsund & & $0.549 * * *$ & $0.747 * * *$ & $0.405^{* * *}$ \\
Palanga & $0.549 * * *$ & & $0.753 * * *$ & $0.306^{* * *}$ \\
Muuga & $0.747 * * *$ & $0.753^{* * *}$ & & NS \\
Mariehamn & $0.405^{* * *}$ & $0.306^{* * *}$ & $N S$ & \\
\hline
\end{tabular}

NS not significant

Italic values are indicated $(P>0.05)$

*** $P<0.0001$ 
infecting the skin and fins of the fish with an intensity of up to 30 capsules per fish $(\mathrm{MI}=9)$ (Table 4). The infection causes a change in pigmentation of the hosts skin around the cysts, which are seen as distinct black spots (black spot disease) on the skin. This is a typical infection of Cryptocotyle concavum/lingua (Creplin, 1825), which has been observed infecting the round goby, as well as, other fish in the southwestern Baltic Sea (Køie, 1999; Rokicki \& Rolbiecki, 2002; Unger et al., 2014). All other parasites were larval stages of nematodes and occurred on the intestinal mesenteries or the body cavity at low intensities (1-4 individuals). Nematodes of the genus Contracaecum infected 12\% of the round gobies in Guldborgsund. Based primarily on the size and site of infection, at least four of these were considered to be Contracaecum rudolphii A or Contracaecum rudolphii C $(P=4 \%, I=4)$. Four encapsulated larvae of an unidentified ascaridoidean nematode species were also found in the mesenteries and body cavity of four round gobies $(P=16 \%)$ (Table 4). Most infected fish only hosted one species of parasite but three individuals were infected by both Cryptocotyle metacercariae and nematode larvae.

\section{Palanga (Lithuania)}

In Palanga, 7 of 25 fish inspected (28\%) were infected by parasites. The species richness was four species with very low intensity, ranging between 1 and 8 individuals ( $\mathrm{MI}=2$; Tables 3,4$)$. The most common parasite was the nematode Hysterothylacium aduncum $(P=16 \%)$, which had a maximum intensity of 7 individuals in one host $(\mathrm{MI}=3)$. Both larvae and adults were identified. One unidentified ascaridoidean larvae was found in the mesentery $(P=4 \%)$. In addition to nematodes, two species of acanthocephalans were identified. Cystacanth stages of Pomphorhynchus laevis (Müller, 1776) were found in the intestinal mesenteries of two fish $(P=8 \%)$. One adult Echinorhynchus gadi (Müller, 1776) was found in the intestine of a round goby $(P=4 \%)$ (Table 4$)$. One individual hosted both $H$. aduncum and $P$. laevis; all others were only infected by one species.

\section{Muиga (Estonia)}

In Muuga, 15 of 25 fish inspected (60\%) were infected by parasites ( $\mathrm{MI}=7$; Table 3). Diplostomum spp. was the most prevalent parasite species infecting 52\% of the round gobies (Table 4). Another digenean trematode species, Tylodelphys clavata (Nordmann, 1831), was found in $12 \%$ of the fish. The metacercariae larvae of Diplostomum spp. occurred in the eye lenses of the fish, whereas $T$. clavata infects the vitreous body. The mean and maximum intensities for these two parasites were 6 and 16, and 4 and 7 individuals, respectively (Table 4). In addition, a few encapsulated ascaridoidean larvae were found embedded in the intestinal wall and mesenteries of the fish $(P=12 \%)$. In Muuga, $16 \%$ of the fish hosted either both species of digenean trematode larvae or digenean trematode larvae and nematode larvae simultaneously, at intensities varying between 2 and 15 . The total mean intensity was 7 and the maximum observed was 16 individuals per one host (Tables 3,4).

\section{Mariehamn (Finland)}

In Mariehamn, 15 of 25 fish inspected (60\%) were infected by parasites. The most common parasite, Diplostomum spp. $(P=40 \%)$, was the same as in Muuga (Table 4). In contrast, the parasite richness (5 species), together with the maximum intensity (36 individuals) were the highest among all sites (Table 4). Three of the parasite taxa were unique and one of these (Corynosoma sp.; Acanthocephala) has not been found in the round goby before. Only one immature individual of Corynosoma sp. $(P=4 \%)$ was found in the intestine of a round goby. Another of the species not found elsewhere was the nematode Camallanus sp., which was found in $8 \%(\mathrm{MI}=2)$ of the round gobies and the third species was the hirudinean Piscicola geometra L., 1761. Piscicola geometra was also the only ectoparasite encountered. Although the two individuals found were no longer attached to the fish hosts when thawed, it is clear they had been attached at the time of capture. Three round gobies $(P=12 \%, \mathrm{MI}=1$; Table 4$)$ also hosted encapsulated ascaridoidean larvae in their intestinal wall. The majority of round gobies hosted only one parasite species, but $8 \%$ were parasitized by both $D$. spathaceum and Camallanus sp.

\section{Discussion}

Currently, 34 metazoan parasite species have been found infecting the round goby within the invaded 
Table 7 Infection rate by parasites of N. melanostomus around the Baltic Sea basin based on the existing literature and the present study

\begin{tabular}{|c|c|c|c|c|c|c|c|}
\hline \multicolumn{4}{|c|}{ Prior literature } & \multicolumn{4}{|l|}{ Present study } \\
\hline $\begin{array}{l}\text { Gulf of } \\
\text { Gdansk }^{\text {a,b,c }}\end{array}$ & $\begin{array}{l}\text { Vistula } \\
\text { lagoon/ } \\
\text { delta }^{\text {d,g,h }}\end{array}$ & $\begin{array}{l}\text { SW Baltic }{ }^{\mathrm{k}} \\
\text { (German }^{\text {coast })^{\mathrm{f}}}\end{array}$ & $\begin{array}{l}\text { Curonian } \\
\text { lagoon/ } \\
\text { Klaipeda strait }\end{array}$ & Guldborgsund & Palanga & Muuga & Mariehamn \\
\hline
\end{tabular}

\section{Monogenea}

Gyrodactylus

X

rugiensis, ad.

\section{Cestoda}

Bothriocephalus $\mathrm{X}$
sp.(scorpii), pl.
Eubothrium
crassum, pl.
Paradilepis
scolecina, pl.
Proteocephalus
filicollis
Proteocephalus
gobiorum

Proteocephalus sp.

X $\quad$ X

X

X

X

X

X

X

Trematoda (Digenea)
Bucephalus polymorphus, met.

\section{Bunodera} luciopercae
Cryptocotyle spp, $\mathrm{X}$ met.

Diplostomum spp., $\quad \mathrm{X}$ met.

Tylodelphys

$\mathbf{X}$ clavata met.

Tylodelphys sp., met.

\section{Nematoda}

Anguillicoloides $\quad \mathrm{X}$
crassus, L3
Camallanus
truncatus
Camallanus

\section{lacustris}

Contracaecum

spp., L3

Contracaecum rudolphii L3

Cosmocephalus obvelatus L3

Cystidicoloides ephemeridarum

Dichelyne minutus $\mathrm{X}$

X
X

X

X

$\mathbf{X}$

$\mathbf{X}$

X

X $\quad$ X

$\mathbf{X}$

X

X

X

X 
Table 7 continued

\begin{tabular}{|c|c|c|c|c|c|c|c|c|}
\hline & \multicolumn{4}{|c|}{ Prior literature } & \multicolumn{4}{|l|}{ Present study } \\
\hline & $\begin{array}{l}\text { Gulf of } \\
\text { Gdansk }^{\text {a,b,c }}\end{array}$ & $\begin{array}{l}\text { Vistula } \\
\text { lagoon/ } \\
\text { delta }^{\text {d,g,h }}\end{array}$ & 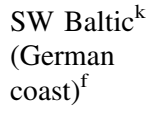 & $\begin{array}{l}\text { Curonian } \\
\text { lagoon/ } \\
\text { Klaipeda strait }\end{array}$ & Guldborgsund & Palanga & Muuga & Mariehamn \\
\hline $\begin{array}{l}\text { Eustrongylides } \\
\text { excisus } \text { L3 }\end{array}$ & & & $X$ & & & & & \\
\hline $\begin{array}{l}\text { Hysterothylacium } \\
\text { aduncum, L3, } \\
\text { L4, ad. }\end{array}$ & $\mathbf{X}$ & $\mathbf{X}$ & & $\mathbf{X}$ & & $\mathbf{X}$ & & \\
\hline $\begin{array}{l}\text { Paracuaria } \\
\text { adunca, L3 }\end{array}$ & & & $X$ & & & & & \\
\hline $\begin{array}{l}\text { Agamonema sp. } \\
\text { L3 }\end{array}$ & & $X$ & & & & & & \\
\hline $\begin{array}{l}\text { Ascaridoidea } \\
\text { indet. }\end{array}$ & & & & & $X$ & $X$ & $X$ & $X$ \\
\hline \multicolumn{9}{|l|}{ Acanthocephala } \\
\hline $\begin{array}{l}\text { Acanthocephalus } \\
\text { anguillae }\end{array}$ & & & & $X$ & & & & \\
\hline $\begin{array}{l}\text { Acanthocephalus } \\
\quad \text { lucii }\end{array}$ & $\mathrm{X}$ & & & & & & & \\
\hline $\begin{array}{l}\text { Echinorhynchus } \\
\quad \text { gadi }\end{array}$ & $\mathbf{X}$ & $\mathbf{X}$ & $\mathbf{X}$ & $\mathbf{X}$ & & $\mathbf{X}$ & & \\
\hline Corynosoma sp. & & & & & & & & $\mathrm{X}$ \\
\hline $\begin{array}{l}\text { Pomphorhynchus } \\
\text { laevis }\end{array}$ & $\mathbf{X}$ & $\mathbf{X}$ & $\mathbf{X}$ & $\mathbf{X}$ & & $\mathbf{X}$ & & \\
\hline \multicolumn{9}{|l|}{ Hirudinea } \\
\hline $\begin{array}{l}\text { Piscicola } \\
\text { geometra }\end{array}$ & $X$ & & & & & & & $X$ \\
\hline \multicolumn{9}{|l|}{ Crustacea } \\
\hline Ergasilus sieboldi & $X$ & & & & & & & \\
\hline \multicolumn{9}{|l|}{ Bivalvia } \\
\hline Unio sp., glochidia & & $X$ & $\mathrm{X}$ & & & & & \\
\hline Total & 13 & 22 & 11 & 7 & 3 & 4 & 3 & 5 \\
\hline Infection rate & $98.7 \%^{3}$ & $18.3^{\mathrm{d}}$ & $58.10 \%{ }^{\mathrm{jf}}$ & - & $56 \%$ & $28 \%$ & $60 \%$ & $60 \%$ \\
\hline
\end{tabular}

The most common parasites are in bold and ectoparasites in grey

Met metacercariae larvae; L3, L4 stage 3 and 4 larvae; cysth cystacanth larvae; $p l$ plerocercoid larvae; ad adult

${ }^{\mathrm{a}}$ Rokicki \& Rolbiecki, 2002, ${ }^{\mathrm{b}} \mathrm{Kvach}, 2001,{ }^{\mathrm{c}} \mathrm{Kvach}$ \& Skóra, 2006, ${ }^{\mathrm{d}}$ Rolbiecki, 2006 (and references therein), ${ }^{\mathrm{e}}$ Rakauskas et al., 2008, ${ }^{\mathrm{f}}$ Kvach \& Winkler 2011, $7{ }^{\mathrm{g}}$ Kvach et al., 2014, $8{ }^{\mathrm{h}}$ Szostakowska \& Fagerholm, 2007

${ }^{\mathrm{i}}$ Identification based on ecological characteristics

j Value given in Kvach \& Winkler, (2011) including microsporidians

k Area of study includes: Szczecin Lagoon, Peenemünde (Peene river), Strelasund strait, Unterwarnow (Mecklenburg bight) and Kiel Canal

Baltic Sea basins and lagoons (Kvach, 2001; Rokicki \& Rolbiecki, 2002; Kvach \& Skóra, 2006; Rolbiecki, 2006; Rakauskas et al., 2008; Kvach \& Winkler, 2011;

Table 7). Most of the taxa have been detected in the Gulf of Gdansk, and Vistula lagoon and river delta (13 and 22 taxa respectively; Table 7). This is expected, as these areas have been inhabited by round gobies the longest, since the early 1990s. Previously, the lowest species richness was reported for the Curonian lagoon, where only 7 parasitic species were found (Rakauskas 
et al., 2008). In the Gulf of Gdansk, round goby populations have shown a clear increase with time in the number of parasites and intensity of infection. The first study in the region only showed five taxa of metazoan endoparasites infecting the round goby (Rokicki \& Rolbiecki, 2002), whereas, a few years later, 12 taxa (8 endoparasite species and 4 ectoparasites) were recorded (Kvach \& Skóra, 2006). The later study also had an infection rate of $98.7 \%$ (Kvach \& Skóra, 2006), which closely resembles the infection rate of $97.5 \%$ reported by Özer (2007) in the goby's native range in the southern Black Sea. However, the mean intensity of parasite infections was much higher $(78.2 \pm 23.1)$ in the Black Sea than in the Gulf of Gdansk. In the invasive range, the round goby also tends to have a lower prevalence of parasites compared to other gobiid species and other fish species (Kvach, 2001, 2004b; Ondračková et al., 2010; Gendron et al., 2012). In the southwestern Baltic region, both species richness (11 species; Table 7; Kvach \& Winkler, 2011) and infection rates (57\%; Table 7; Kvach \& Winkler, 2011) are lower than in other gobiid species, which all host a range of 14-24 parasite species and have infection rates regularly attaining 100\% (Zander, 2003).

The parasite taxa richness in the present study is quite low (3-5 species; Tables 4, 7). Nevertheless, many of the most common species found in the present study are the same as in the previous investigations. Digenean trematode larvae of the species Diplostomum spp. have been observed as the most prevalent parasites in many previous studies in the Baltic Sea (Kvach \& Skóra, 2006; Kvach \& Winkler, 2011; Kvach et al., 2014; Table 7), as well as, other native and non-native areas (Kvach \& Skóra, 2006; Kvach \& Stepien, 2008; Francová et al., 2011; Gendron et al., 2012). In this study, it was found to be the most common parasite with the highest prevalence and intensity in Muuga and Mariehamn (Table 3), but absent from the two other sites. Diplostomum spp. together with another digenean trematode species, Cryptocotyle sp. observed in Guldborgsund, were the only species reaching high prevalence and intensities (Table 4).

Of the nematode species observed in this study, Hysterothylacium aduncum has frequently been reported infecting the round goby in all areas except the southwestern Baltic Sea (Kvach \& Winkler, 2011; Table 7). This is despite the fact that $H$. aduncum does occur quite commonly in the area and has been recorded in native goby species (Zander, 2003). The acanthocephalans Echinorhynchus gadi and Pomphorhynchus laevis, which were found in Palanga (Table 4), are also common species reported for the round goby in the Baltic Sea, as well as, other brackish and freshwater native and non-native areas (Kvach \& Skóra, 2006; Francová et al., 2011; Table 7). Hysterothylacium aduncum and E. gadi are both fish parasites of marine origin which are commonly found in eelpout (Zoarces viviparus L., 1758) and cod (Gadus morhua L., 1758), but can also be found in other fish species (Fagerholm, 1982; Valtonen, 2012).

Larvae of Contracaecum osculatum, a mammalian parasite infecting mostly seals, have been observed in the round goby in the Vistula lagoon (Rolbiecki, 2006), but the distinction between $C$. osculatum and $C$. rudolphii larvae is often difficult and thus some specimens may have been misidentified. However, $C$. rudolphii found in this study in Danish and Lithuanian round gobies is an avian parasite, maturing primarily in cormorants (Szostakowska \& Fagerholm, 2007, 2012). Cormorants have been known to prey actively on round gobies where they co-occur, e.g. in the Gulf of Gdansk (Bzoma, 1998) and the Curonian Lagoon (Rakauskas et al., 2013). Thus, round goby is a potential paratenic host in completing the life cycle of this $C$. rudolphii in the Danish and Lithuanian populations (Table 4).

This study gives a new host record for the acanthocephalan Corynosoma sp. parasitizing round gobies in the Baltic Sea. The taxon was observed in Mariehamn, Finland (Table 4). The three species in the genus Corynosoma occurring in the Baltic Sea are all primarily seal parasites and mainly use the amphipod Monoporeia affinis (Lindström, 1855) and sculpins or other fish as the intermediate and paratenic hosts (Valtonen, 2012). So far, there has been no evidence of seals using round gobies as prey. However, the migration patterns of the round goby in the Baltic Sea are still poorly understood and it is possible that during autumn and early winter as they migrate to deeper water and possibly further offshore, seals could prey on round gobies. Thus, the round goby may act as an alternative host in the life cycle of Corynosoma sp. It is also possible that the round goby is merely a "dead-end" paratenic host for these species and could thus contribute to a diluting effect for these parasites if they do not reach their definitive hosts. However, with 
such low infection intensities in the round goby, the aforementioned ecological effects are likely to be restricted.

The observed parasite species are all generalists and occur commonly in the Baltic Sea. The fact that the round goby shows lower infection rates than other benthic fish species in the invaded area (Kvach \& Winkler, 2011), together with the lack of any specialized and/or non-native parasites (Kvach, 2001; Kvach \& Skóra, 2006), complies with the theory of enemy release in the Baltic populations (Torchin et al., 2003; Colautti et al., 2004). We suggest that a similar increase in parasite infection prevalence and intensity, as was seen in the Gulf of Gdansk, may be expected in the northern populations, sampled in this study, as the native parasites gradually adapt to and colonize this new host species.

The Baltic Sea parasite fauna, similarly to the Baltic Sea fauna and flora in general, is a heterogeneous assemblage of species of freshwater, marine and brackish water origin (Fagerholm, 1982; Køie, 1999; Zander \& Reimer, 2002). Some changes in the parasitic fauna of the round goby can thus be observed due to differing salinity in the southern/southwestern population (Denmark) compared to the northern populations (Estonia and Finland). The increase of Diplostomum spp. and decrease of Cryptocotyle sp. has often been observed in studies following a southwest to northeast salinity gradient in the Baltic Sea (Køie, 1999; Unger et al., 2014). The low similarity between the locations (Tables 3, 4 and 7) might thus be explained by the difference in salinity, which causes significant differences in benthic fauna composition and, consequently, in parasite fauna that rely on these species as intermediate and paratenic hosts (Williams et al., 1992; Zander \& Reimer, 2002). The parasite composition is probably a reflection of the salinity tolerance of both the parasite species and its intermediate host species. It would seem that in general the infection rate is higher in low and intermediate salinities, like in the Vistula and Szczecin lagoons (Rolbiecki, 2006; Kvach \& Winkler, 2011; Table 7), as well as, in Mariehamn and Muuga (Table 3). The round goby seems to host a mix of parasites of both limnic and marine origin throughout the Baltic Sea, albeit clearly dominated by a few limnic species.

Due to complex life histories of many parasites, completing their life cycle depends on access to suitable hosts in the system. In this study, the lack of gastropods in the diet of the round goby in Palanga $(\mathrm{FO}=5.6 \%$; Table 8$)$, indicates an absence of gastropod species in the habitat and thus appeared to be reflected in an absence of some parasite species, especially digenean trematodes of the genera $\mathrm{Di}$ plostomum, Tylodelphys and Cryptocotyle, which use gastropods as intermediate hosts for the metacercariae larvae (Zander, 2003; Valtonen \& Gibson, 1997). The lower infection rate in Lithuania $(28 \%)$ is probably a result of this absence of digenean trematode larvae, which account for the highest prevalence at all other sites (Table 4). The absence of Diplostomum spp. metacercariae in Palanga is noteworthy, since it was the most prevalent parasite (13.5\%) in 2007 (Rakauskas et al., 2008) and has also been reported in other fish species along the Lithuanian and Latvian coasts (Tabolina, 1994; Køie, 1999).

The lack of copepods in the diet of $N$. melanostomus at the study locations (Table 8 ) is a probable cause of the lack of cestode parasites observed in this study, since planktonic crustaceans are their primary intermediate hosts (Scholz, 1999). Together with the absence of cestode species, the lack of metazoan ectoparasites in this study is also contributing to the low species richness. The most likely reason is salinity as well as time since introduction. Most metazoan ectoparasites that have previously been found infecting the round goby in the Baltic Sea (crustacean Ergasilus sieboldi, Nordmann 1832 and the glochid stages of unionid bivalves) are freshwater species. The salinity in the sampling areas (5 to 7 PSU; Table 1), is thus probably too high for these species to occur. The monogenean Gyrodactylus rugiensis, on the other hand, is a marine parasite normally infecting Pomatoschistus microps, and it has previously been found infecting the round goby in salinities above 9 PSU in the Baltic (Kvach \& Winkler, 2011). Monogeneans are in general quite host specific (Poulin, 2002; Huyse et al., 2003), and the introduction of the round goby in these locations happened 10-15 years ago, which is likely not enough time for most native monogeneans to adapt or switch host. The gobyspecific monogenean, Gyrodactylus proterorhini, infects the round goby in its native areas in Black sea and Sea of Azov, but has to date not been observed in the Baltic round gobies (Mierzejewska et al., 2011). Other metazoan ectoparasites, mainly copepods, e.g. Ergasilus sieboldi, are found only occasionally even in 
Table 8 The frequency of occurrence (\%) of prey items (taxa) in the stomach contents of round gobies examined for parasites at four different locations in the Baltic Sea

\begin{tabular}{|c|c|c|c|c|c|c|c|c|c|c|c|}
\hline \multirow[t]{2}{*}{ Taxa } & \multicolumn{3}{|c|}{ Guldborgsund } & \multicolumn{3}{|c|}{ Palanga } & \multicolumn{3}{|c|}{ Muuga } & \multicolumn{2}{|c|}{ Mariehamn } \\
\hline & $\begin{array}{l}\text { Total } \\
22\end{array}$ & $\begin{array}{l}\mathrm{F} \\
10\end{array}$ & $\begin{array}{l}M \\
12\end{array}$ & $\begin{array}{l}\text { Total } \\
18\end{array}$ & $\begin{array}{l}\mathrm{F} \\
7\end{array}$ & $\begin{array}{l}\text { M } \\
11\end{array}$ & $\begin{array}{l}\text { Total } \\
22\end{array}$ & $\begin{array}{l}F \\
11\end{array}$ & $\begin{array}{l}M \\
11\end{array}$ & $\begin{array}{l}\text { Total } \\
21\end{array}$ & $\begin{array}{l}M \\
21\end{array}$ \\
\hline Mytilus & 4.5 & & 8.3 & 22.2 & 14.3 & 27.3 & 13.6 & & 27.3 & 9.5 & 9.5 \\
\hline Macoma & & & & & & & 45.5 & 72.7 & 18.2 & 19.0 & 19.0 \\
\hline Bivalvia indet. & 4.5 & & 8.3 & & & & & & & & \\
\hline Amphibalanus & 9.1 & 10.0 & 8.3 & 50.0 & 14.3 & 72.7 & 54.5 & 27.3 & 81.8 & 42.9 & 42.9 \\
\hline Gastropoda & 50.0 & 50.0 & 50.0 & 5.6 & & 9.1 & 13.6 & 9.1 & 18.2 & 66.7 & 66.7 \\
\hline Amphipoda & & & & 61.1 & 28.6 & 81.8 & 18.2 & & 36.4 & 9.5 & 9.5 \\
\hline Isopoda & 9.1 & 10.0 & 8.3 & 22.2 & 28.6 & 18.2 & & & & & \\
\hline Decapoda & 9.1 & 10.0 & 8.3 & 16.7 & & 27.3 & & & & 4.8 & 4.8 \\
\hline Polychaeta & 22.7 & 30.0 & 16.7 & 11.1 & 28.6 & & 9.1 & 9.1 & 9.1 & & \\
\hline Oligochaeta & 4.5 & 10.0 & & 5.6 & 14.3 & & 9.1 & 9.1 & 9.1 & 4.8 & 4.8 \\
\hline Insecta & 18.2 & 10.0 & 25.0 & 5.6 & & 9.1 & 18.2 & 9.1 & 27.3 & 9.5 & 9.5 \\
\hline Other & 9.1 & 10.0 & 8.3 & & & & & & & & \\
\hline N. melanostomus $\mathrm{s}^{\mathrm{a}}$ & 72.7 & 60.0 & 83.3 & 33.3 & 14.3 & 45.5 & 22.7 & 9.1 & 36.4 & 23.8 & 23.8 \\
\hline Pisces undetermined $^{\mathrm{a}}$ & 9.1 & & 16.7 & & & & 9.1 & 18.2 & & 14.3 & 14.3 \\
\hline Pisces eggs & 4.5 & 10.0 & & & & & & & & & \\
\hline
\end{tabular}

At each location, the number of fish with stomach contents is given $(n)$. All values are given separately for males and females as well as in total for each location

a Scales and bones

its native area (Kvach, 2004b; Rolbiecki, 2006 and references therein; Özer, 2007). The only ectoparasite in this study, the hirudinea $P$. geometra, is very common in the Baltic Sea and has low host specificity as it infects several species of fish, e.g. eel (Rolbiecki, 2006), eelpout Zoarces viviparus (L., 1758), and Baltic flounder Platichthys flesus (L., 1758) (Køie, 1999). However, it has to be noted that the relatively small sample size ( $25 \mathrm{fish} / \mathrm{site}$ ) can have caused some rare species not to be detected.

The most prevalent parasites in Guldborgsund, Muuga and Mariehamn, digenean trematodes, also correspond to the predominant prey items, i.e. gastropods, at these sites $(\mathrm{FO}=50,13.6$, and $66.7 \%$, respectively; Table 8). Likewise, the occurrence of amphipods in the stomach contents in Palanga $(\mathrm{FO}=61.1 \%$; Table 8$)$ is seen in the presence of acanthocephalan parasites (Table 4). Although characterized as an opportunistic feeder (Rakauskas et al., 2008; Järv et al., 2011), the main components of the round goby diet are usually molluscs and adult barnacle Amphibalanus improvisus Darwin, 1854, which can locally be a dominating prey species (Herlevi, unpubl. data; Table 8). Contracaecum osculatum may infect larval stages of $A$. improvisus, but parasites which would use adult A. improvisus as an intermediate host are not known. There are also no other known predators for adult A. improvisus, although it is occasionally consumed by benthic predators as a fouling species on, e.g. Mytilus trossulus L., 1758 (Laudien \& Wahl, 1999). A few freshwater digenean trematodes parasitizing fish and using bivalves as intermediate hosts have been found in the round goby (Bucephalus polymorphus, Bunodera luciopercae; Table 7), but these species require a freshwater bivalve species as vectors (Dreissena polymorpha Pallas, 1771 or Pisidium spp.). None of the common parasites infecting bivalves such as Mytilus trossulus, Macoma balthica L., 1758 or Cerastoderma spp. in the Baltic have been observed to infect round gobies (Zander \& Reimer, 2002). As these species most commonly share habitat and are important prey of the round goby, it is possible that the round gobies are not exposed to many parasites 
capable of infecting them. This can explain the low intensity of infection in the Baltic Sea. The diet composition of the round goby also explains some of the differences compared to native gobies, since other native goby species are parasitized mainly through ingesting intermediate hosts such as planktonic crustaceans, amphipods and oligochaetes. Thus, the reason for lower parasitization may be the round goby's main prey items and habitat (Zander, 2003; Emde et al., 2014).

The diet of the round goby and the regional differences therein thus seem to explain the intensity of parasitization and parasite assemblages observed in this study. The pattern of parasitization would indicate that the round goby has found a niche, which enables it to escape parasitization by many common parasites in the Baltic Sea. However, since the diet of the round goby has been shown to vary both seasonally and between size groups (e.g. Skora \& Rzeznik, 2001; Rakauskas et al., 2008, 2013; Brandner et al., 2013b; Ustups et al., 2015), future parasitological studies should investigate both seasonal and size-related differences in the infection rates of the round goby in the Baltic Sea.

\section{Conclusions}

The round goby acts as an intermediate and paratenic host for most of the parasite species found in this study. However, the presence of adult individuals of Hysterothylacium aduncum, Camallanus sp., and Echinorhynchus gadi shows that it can also function as a definitive host for these parasite species. Based on this study and others previously conducted in the Baltic Sea, it seems that overall the round goby has not retained parasites from its area of origin, but instead has been successively colonized by generalist parasites in the introduced areas. Although variable, overall parasite richness is still quite low in the Baltic compared to the native areas and a similar pattern can be seen in the prevalence and mean intensities of infection (Kvach, 2001, 2004b; Özer, 2007). The present study thus adds to the evidence supporting the enemy release hypothesis (e.g. Kvach \& Stepien, 2008; Emde et al., 2014; Kvach et al., 2014), as no non-native parasites were detected, and the infection rates remain quite low throughout the invaded areas. The diet and opportunistic feeding behaviour, which enable the round goby to exploit prey items largely unutilized by other predators, are probably a key factor for the observed low parasite intensities, and continued success as an invasive species in the Baltic Sea.

Acknowledgements This work resulted from the BONUS Bio-C3 project and was supported by BONUS (Art 185), funded jointly by the EU and the Academy of Finland. Riikka Puntila's participation was partly supported by a $\mathrm{PhD}$ grant from Maj and Tor Nessling's foundation. We are also eternally thankful for the help from people in our different sampling locations: Mads Christoffersson and Jeff Rømer in Denmark, Linas Lozys in Lithuania and Andres Jaanus and Kristiina Nurkse in Estonia. We would also like to thank the two anonymous reviewers for their valuable and constructive comments on the manuscript, as well as the helpful advice of Marianne Køie and Erkki Leppäkoski.

Open Access This article is distributed under the terms of the Creative Commons Attribution 4.0 International License (http:// creativecommons.org/licenses/by/4.0/), which permits unrestricted use, distribution, and reproduction in any medium, provided you give appropriate credit to the original author(s) and the source, provide a link to the Creative Commons license, and indicate if changes were made.

\section{References}

Arai, H. P., 1989. Acanthocephala, p. 1-90. In L. Margolis \& Z. Kabata (eds), Guide to the parasites of fishes of Canada. Part III. Canadian Special Publication of Fisheries and Aquatic Sciences 107: 95 p.

Azour, F., M. van Deurs, J. Behrens, H. Carl, K. Hüssy, K. Greisen, R. Ebert \& P. Møller, 2015. Invasion rate and population characteristics of the round goby Neogobius melanostomus: effects of density and invasion history. Aquatic Biology 24: 41-52.

Borcherding, J., S. Staas, S. Kruger, M. Ondrackova, L. Slapansky \& P. Jurajda, 2011. Non-native Gobiid species in the lower River Rhine (Germany): Recent range extensions and densities. Journal of Applied Ichthyology 27: 153-155.

Brandner, J., A. F. Cerwenka, U. K. Schliewen \& J. Geist, 2013a. Bigger Is Better: Characteristics of Round Gobies Forming an Invasion Front in the Danube River. PLoS ONE 8(9): e73036.

Brandner, J., A. F. Cerwenka, U. K. Schliewen \& J. Geist, 2013b. Comparative feeding ecology of invasive PontoCaspian gobies. Hydrobiologia 703: 113-131.

Bzoma, S., 1998. The contribution of round goby (Neogobius melanostomus Pallas, 1811) to the food supply of cormorants (Phalacrocorax carbo Linnaeus, 1758) feeding in the Puck Bay. Bulletin of the Sea Fisheries Institute 2: 39-47.

Clarke, K.R. \& R.N. Gorley, 2006. User Manual/Tutorial. PRIMER-E v6, Plymouth, 192 pp. http://www.primer-e. com/. 
Colautti, R. I., A. Ricciardi, I. A. Grigorovich \& H. J. MacIsaac, 2004. Is invasion success explained by the enemy release hypothesis? Ecology Letters 7: 721-733.

Critchlow, D. E. \& M. A. Fligner, 1991. On distribution-free multiple comparisons in the one-way analysis of variance. Communications in Statistics - Theory and Methods 20: 127-139.

Emde, S., S. Rueckert, H. W. Palm \& S. Klimpel, 2012. Invasive Ponto-Caspian Amphipods and Fish Increase the Distribution Range of the Acanthocephalan Pomphorhynchus tereticollis in the River Rhine. PLoS ONE 7: e53218.

Emde, S., J. Kochmann, T. Kuhn, M. Plath \& S. Klimpel, 2014. Getting What Is Served? Feeding Ecology Influencing Parasite-Host Interactions in Invasive Round Goby Neogobius melanostomus. PLoS ONE 9: e109971.

Fagerholm, H.-P., 1982. Parasites of fish in Finland. IV. Nematodes. Acta Academiae aboensis, Series B 40: 1-128.

Florin, A.-B. \& M. Karlsson, 2011. Svartmunnad smörbult i svenska kustområden. Finfo., https://www.slu.se/ PageFiles/98817/Finfo 2011_2_mindre.pdf.

Francová, K., M. Ondračková, M. Polačik \& P. Jurajda, 2011. Parasite fauna of native and non-native populations of Neogobius melanostomus (Pallas, 1814) (Gobiidae) in the longitudinal profile of the Danube River. Journal of Applied Ichthyology 27: 879-886.

Fulton, T. W., 1904. The rate of growth of fishes. Fisheries Board of Scotland, Annual Report 22 part 3: 141-241.

Gendron, A. D., D. J. Marcogliese \& M. Thomas, 2012. Invasive species are less parasitized than native competitors, but for how long? The case of the round goby in the Great LakesSt. Lawrence Basin. Biological Invasions 14: 367-384.

Strake, S., Perkons, V., Yermakov, V., Minde, A., Kazmers, I., Kruze, E., Romanovich, S., Medne, R., Zagars, M., Ojaveer, H., Kotta I., Jaanus, A. \& A. Põllumäe, 2013. Report on the field studies on alien species: GES-REG Project partners, $57 \mathrm{pp}$.

Gutowsky, L. F. G. \& M. G. Fox, 2012. Intra-population variability of life history traits and growth during range expansion of the invasive round goby (Neogobius melanostomus). Fisheries Management and Ecology 19: 78-88.

Hudson, P. J., A. P. Dobson \& K. D. Lafferty, 2006. Is a healthy ecosystem one that is rich in parasites? Trends in ecology \& evolution 21: 381-385.

Huyse, T., V. Audenaert \& F. A. M. Volckaert, 2003. Speciation and host-parasite relationships in the parasite genus $G y$ rodactylus (Monogenea, Platyhelminthes) infecting gobies of the genus Pomatoschistus (Gobiidae, Teleostei). International Journal for Parasitology 33: 1679-1689.

Huyse, T., M. P. M. Vanhove, M. Mombaerts, F. A. M. Volckaert \& H. Verreycken, 2015. Parasite introduction with an invasive goby in Belgium: double trouble? Parasitology Research 114: 2789-2793.

Hyslop, E. J., 1980. Stomach contents analysis - a review of methods and their application. Journal of Fish Biology 17: 411-429.

Höglund, J. \& J. Thulin, 1982. Identification of Diplostomum spp. in the retina of perch Perca fluviatilis and the lens of roach Rutilus rutilus from the Baltic Sea - an experimental study. Systematic Parasitology 21: 1-19.
Järv, L., J. Kotta, I. Kotta \& T. Raid, 2011. Linking the structure of benthic invertebrate communities and the diet of native and invasive fish species in a brackish water ecosystem. Annales Zoologici Fennici 48: 129-141.

Johnsen, B. O. \& A. J. Jenser, 1991. The Gyrodactylus story in Norway. Aquaculture 98: 289-302.

Karsiotis, S. I., L. R. Pierce, J. E. Brown \& C. A. Stepien, 2012. Salinity tolerance of the invasive round goby: Experimental implications for seawater ballast exchange and spread to North American estuaries. Journal of Great Lakes Research 38: 121-128.

Kelly, D. W., R. A. Paterson, C. R. Townsend, R. Poulin \& D. M. Tompkins, 2009. Parasite spillback: a neglected concept in invasion ecology? Ecology 90: 2047-2056.

Kirk, R. S., 2003. The impact of Anguillicola crassus on European eels. Fisheries Management and Ecology 10: 385-394.

Køie, M., 1999. Metazoan parasites of flounder Platichthys flesus (L.) along a transect from the southwestern to the northeastern Baltic Sea. ICES Journal of Marine Science 56: $157-163$.

Kopp, K. \& J. Jokela, 2007. Resistant invaders can convey benefits to native species. Oikos 116: 295-301.

Kornis, M. S., N. Mercado-Silva \& M. J. Vander Zanden, 2012. Twenty years of invasion: a review of round goby Neogobius melanostomus biology, spread and ecological implications. Journal of fish biology 80: 235-285.

Kornis, M. S., S. Sharma \& M. Jake Vander Zanden, 2013. Invasion success and impact of an invasive fish, round goby, in Great Lakes tributaries. Diversity and Distributions 19: 184-198.

Kotta, J., K. Nurkse, R. Puntila \& H. Ojaveer, 2016. Shipping and natural environmental conditions determine the distribution of the invasive non-indigenous round goby Neogobius melanostomus in a regional sea. Estuarine, Coastal and Shelf Science 169: 15-24.

Kvach, Y., 2001. The round goby parasites in native habitats and in a place of invasion. Oceanological Studies 31: 51-57.

Kvach, Y., 2004a. The Far-Eastern nematode Anguillicola crassus - new parasite of the invasive round goby Neogobius melanostomus in the Baltic Sea. Vestnik Zoologii 38: 38 .

Kvach, Y., 2004b. The metazoa parasites of gobiids in the Dniester Estuary (Black Sea) depending on water salinity. Oceanological and Hydrobiological Studies 33: 47-56.

Kvach, Y., 2005. A comparative analysis of helminth faunas and infection parameters of ten species of Gobiid fishes (actinopterygii: Gobiidae) from the North-Western Black Sea. Acta Ichthyologica et Piscatoria 35: 103-110.

Kvach, Y. \& K. E. Skóra, 2006. Metazoa parasites of the invasive round goby Apollonia melanostoma (Neogobius melanostomus) (Pallas) (Gobiidae: Osteichthyes) in the Gulf of Gdańsk, Baltic Sea, Poland: A comparison with the Black Sea. Parasitology Research 100: 767-774.

Kvach, Y. \& C. A. Stepien, 2008. Metazoan Parasites of Introduced Round and Tubenose Gobies in the Great Lakes: Support for the "Enemy Release Hypothesis". Journal of Great Lakes Research 34: 23-35.

Kvach, Y. \& H. M. Winkler, 2011. The colonization of the invasive round goby Neogobius melanostomus by parasites 
in new localities in the southwestern Baltic Sea. Parasitology Research 109: 769-780.

Kvach, Y., Y. Kornyychuk, K. Mierzejewska, N. Rubtsova, V. Yurakhno, J. Grabowska \& M. Ovcharenko, 2014. Parasitization of invasive gobiids in the eastern part of the Central trans-European corridor of invasion of PontoCaspian hydrobionts. Parasitology Research 113: 1605-1624.

Laudien, J. \& M. Wahl, 1999. Indirect effects of epibiosis on host mortality: seastar predation on differently fouled mussels. Marine Ecology 20: 35-47.

Lymbery, A. J., M. Morine, H. G. Kanani, S. J. Beatty \& D. L. Morgan, 2014. Co-invaders: The effects of alien parasites on native hosts. International Journal for Parasitology: Parasites and Wildlife Australian Society for Parasitology 3: 171-177.

MacInnis, A. J. \& L. D. Corkum, 2000. Fecundity and reproductive season of the round goby Neogobius melanostomus in the upper Detroit River. Transactions of the American Fisheries Society 129: 136-144.

Mierzejewska, K., A. Martyniak, T. Kakareko, E. Dzika, K. Stańczak \& P. Hliwa, 2011. Gyrodactylus proterorhini Ergens, 1967 (Monogenoidea, Gyrodactylidae) in gobiids from the Vistula River - The first record of the parasite in Poland. Parasitology Research 108: 1147-1151.

Moravec, F., 1994. Parasitic nematodes of freshwater fishes of Europe. Cluwer Academic Publishers, Dordrecht: 473.

Ojaveer, H., 2006. The round goby Neogobius melanostomus is colonising the NE Baltic Sea. Aquatic Invasions 1: 44-45.

Ojaveer, H. \& J. Kotta, 2015. Ecosystem impacts of the widespread non-indigenous species in the Baltic Sea: literature survey evidences major limitations in knowledge. Hydrobiologia 750: 171-185.

Ojaveer, H., B. S. Galil, M. Lehtiniemi, M. Christoffersen, S. Clink, A.-B. Florin, P. Gruszka, R. Puntila \& J. W. Behrens, 2015. Twenty five years of invasion: management of the round goby Neogobius melanostomus in the Baltic Sea. Management of Biological Invasions 6: 329-339.

Ondračková, M., K. Francová, M. Dávidová, M. Polačik \& P. Jurajda, 2010. Condition status and parasite infection of Neogobius kessleri and N. melanostomus (Gobiidae) in their native and non-native area of distribution of the Danube River. Ecological Research 25: 857-866.

Özer, A., 2007. Metazoan parasite fauna of the round goby Neogobius melanostomus Pallas, 1811 (Perciformes: Gobiidae) collected from the Black Sea coast at Sinop, Turkey. Journal of Natural History 41: 483-492.

Palm, H.W., 2011. Fish Parasites as Biological Indicators in a Changing World: Can We Monitor Environmental Impact and Climate Change? H. Mehlhorn (ed), Progress in Parasitology, Parasitology Research Monographs 2

Peeler, E. J., B. C. Oidtmann, P. M. Midtlyng, L. Miossec \& R. E. Gozlan, 2010. Non-native aquatic animal introductions have driven disease emergence in Europe. Biological Invasions 13: 1291-1303.

Poulin, R., 2002. The evolution of monogenean diversity. International Journal for Parasitology 32: 245-254.

Prenter, J., C. MacNeil, J. T. A. Dick \& A. M. Dunn, 2004. Roles of parasites in animal invasions. Trends in Ecology \& Evolution 19: 385-390.
Rakauskas, V., E. Bacevičius, Ž. Pūtys, L. Ložys \& K. Arbačiauskas, 2008. Expansion, Feeding and Parasites of the Round Goby, Neogobius melanostomus (Pallas, 1811), a recent invader in the Curonian Lagoon, Lithuania. Acta Zoologica Lituanica 18: 180-190.

Rakauskas, V., Ž. Pūtys, J. Dainys, J. Lesutienè, L. Ložpys \& K. Arbačiauskas, 2013. Increasing Population of the Invader Round Goby, Neogobius melanostomus (Actinopterygii: Perciformes: Gobiidae), and its Trophic Role in the Curonian Lagoon, Se Baltic Sea. Acta Ichthyologica Et Piscatoria 43: 95-108.

Reiczigel, J. \& L. Rózsa, 2005. Quantitative Parasitology 3.0. Distributed by the authors, Budapest, http://www2.univet. hu/qpweb/.

Rokicki, J. \& L. Rolbiecki, 2002. Colonization of the round goby, Neogobius melanostomus (Gobiidae) by parasites in the new environment of the Gulf of Gdansk (Southern Baltic). Wiadomosci Parazytologiczne 48: 197-200.

Rolbiecki, L., 2006. Parasites of the round goby, Neogobius melanostomus (Pallas, 1811), an invasive species in the Polish fauna of the Vistula Lagoon ecosystem. Oceanologia 48: 545-561.

Rózsa, L., J. Reiczigel \& G. Majoros, 2000. Quantifying Parasites in Samples of Hosts. Journal of Parasitology 86: 228-232.

Ruiz, G. M., P. Fofonoff, A. H. Hines \& E. D. Grosholz, 1999. Non-indigenous species as stressors in estuarine and marine communities: Assessing invasion impacts and interactions. Limnology and Oceanography 44: 950-972.

Sapota, M. R., 2004. The round goby (Neogobius melanostomus) in the Gulf of Gdansk- a species introduction into the Baltic Sea. Hydrobiologia 514(219-224): 2004.

Sapota, M. R., 2011. NOBANIS - Invasive Alien Species Fact Sheet - Neogobius melanostomus. Online Database of the European Network on Invasive Alien Species - NOBANIS. www.nobanis.org.

Sapota, M. R. \& K. E. Skora, 2005. Spread of alien (nonindigenous) fish species Neogobius melanostomus in the Gulf of Gdansk (south Baltic). Biological Invasions 7: 157-164.

SAS Institute Inc., 2013. JMP Pro 11.

Scholz, T., 1999. Life cycles of species of Proteocephalus, parasites of fishes in the Palearctic Region: a review. Journal of Helminthology 73: 1-19. doi: 10.1017/ S0022149X99000013

Skora, K. E. \& J. Rzeznik, 2001. Observations on Diet Composition of Neogobius melanostomus Pallas 1811 (Gobiidae, Pisces) in the Gulf of Gdansk (Baltic Sea). Journal of Great Lakes Research 27: 290-299.

Skora, K. E. \& J. Stolarski, 1993. New fish species in the Gulf of Gdansk Neogobius sp. [cf. Neogobius melanostomus (Pallas 1811)]. Bulletin of the Sea Fisheries Institute 1: 83.

Špakulová, M., M.-J. Perrot-Minnot \& B. Neuhaus, 2011. Resurrection of Pomphorhynchus tereticollis (Rudolphi, 1809) (Acanthocephala: Pomphorhynchidae) based on new morphological and molecular data. Helminthologia 48: 268-277.

Szostakowska, B. \& H.-P. Fagerholm, 2007. Molecular identification of two strains of third-stage larvae of Contracaecum rudolphii sensu lato (Nematoda: Anisakidae) from fish in Poland. The Journal of Parasitology 93: 961-964. 
Szostakowska, B. \& H.-P. Fagerholm, 2012. Coexistence and genetic variability of Contracaecum rudolphii $\mathrm{A}$ and Contracaecum rudolphii B (Nematoda: Anisakidae) in cormorants, Phalacrocorax carbo sinensis, in the Baltic region. The Journal of Parasitology 98: 472-478.

Tabolina, I., 1994. Parasites and diseases of flounder in the coastal waters of Latvia In Bylund, G. \& L.-G. Lönnström (eds), Diseases and parasites of flounder in the Baltic Sea. The Baltic Marine Biologists Publication No 15: 61-63.

Torchin, M. E., K. D. Lafferty, A. P. Dobson, V. J. McKenzie \& A. M. Kuris, 2003. Introduced species and their missing parasites. Nature 421: 628-630.

Unger, P., S. Klimpel, T. Lang \& H. Palm, 2014. Metazoan parasites from herring (Clupea harengus L.) as biological indicators in the Baltic Sea. Acta Parasitologica 59: 518-528.

Ustups, D., U. Bergström, A. B. Florin, E. Kruze, D. Zilniece, D. Elferts, A. Knospina \& H. Uzars, 2015. Diet overlap between juvenile flatfish and the invasive round goby in the central Baltic Sea. Journal of Sea Research 107: 121-129.

Valtonen, T. E., 2012. Pääjakso väkäräkärsämadot (Acanthocephala). In Valtonen, T. E., T. Hahalahti-Sirén, A.
Karvonen \& K. Pulkkinen (eds), Suomen kalojen loiset. Gaudeamus, Tampere.

Valtonen, T. E. \& D. I. Gibson, 1997. Aspects of the biology of diplostomid metacercarial (Digenea) populations occurring in fishes in different localities of Northern Finland. Annales Zoologici Fennici 34(1): 47-59.

van Beek, G. C. W., 2006. The round goby Neogobius melanostomus first recorded in the Netherlands. Aquatic Invasions 1: 42-43.

Williams, H. H., K. MacKenzie \& A. M. McCarthy, 1992. Parasites as biological indicators of the population biology, migrations, diet, and phylogenetics of fish. Reviews in Fish Biology and Fisheries 2: 144-176.

Zander, C. D., 2003. Four-year monitoring of parasite communities in gobiid fishes of the southwestern Baltic-I. Guild and component community. Parasitology Research 90: 502-511.

Zander, C. D. \& L. W. Reimer, 2002. Parasitism at the ecosystem level in the Baltic Sea. Parasitology 124: 119-135. 